\title{
Viabilidade Bacteriana em Produto Fermentado
}

Magali Pozza (I), Grasiele Scaramal Madrona (I), Maximiliane Alarvase Zambom (II), Marcela Abbado Neres (II), Paulo Cesar Pozza (I)

(I) UEM - Universidade Estadual de Maringá (Av colombo 5790 jardim universitario), (II) Unioeste - Universidade Estadual do Oeste do Paraná (Rua pernambuco 1777 Marechal cândid Rondon)

\section{Resumo}

Atualmente, um vegetal que vem sendo muito estudado por apresentar até $20 \%$ do peso fresco de inulina e oligofrutose é o yacon (Smallanthus sonchifolius). O objetivo deste trabalho foi avaliar a viabilidade celular de bebida fermentada elaborada com extrato de yacon. O extrato foi padronizado para $4^{\circ}$ Brix de sólidos solúveis. Após a fermentação o produto foi mantido sob refrigeração para maturação por $24 \mathrm{hs}$. As formulações foram: T1 (controle), T2 (5\% do extrato de yacon), T3 (10\% de yacon) e T4 (15\% de yacon) sendo adicionados de $8 \%$ de açúcar. Foi utilizada cultura probiótica: Bio Rich ${ }^{\circledR}$ - fermento láctico probiótico que contém culturas selecionadas e superconcentradas de L. acidophilus LA-5, Bifidobacterium BB-12 e S. thermophilus, Para a contagem total de bactérias, diluições foram inoculadas nos tempos 1, 7,21 e 28 dias em ágar padrão para contagem (Plate Count Agar) e as placas incubadas a $32^{\circ} \mathrm{C} / 48$ horas. Para contagem de bactérias láticas utilizou-se ágar MRS e incubação a $35^{\circ} \mathrm{C} / 48$ horas. Foram observadas interações significativas para as variáveis em estudo. Com relação aos tratamentos contendo diferentes níveis de inclusão de yacon (T2, T3 e T4) as maiores contagens de bactérias lácticas. 
Palavras-Chave: bebida lactea, simbiótico, alimentos Agência de Fomento: 